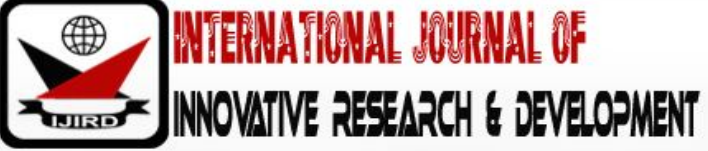

ISSN 2278 - 0211 (Online)

\section{Career Guidance and Counselling in Uganda, Current Developments and Challenges}

\author{
Otwine Anne \\ Student, School of Psychology, Makerere University, Uganda \\ Oonyu Joseph \\ Associate Professor, School of Education, Makerere University, Uganda \\ John M. Kiweewa \\ Associate Professor, School of Psychology, Makerere University \\ Said Nsamba \\ Assistant Commissioner Department of Guidance' and Counselling, \\ Ministry of education and Sports, Uganda
}

\begin{abstract}
:
Uganda like other countries in the Saharan sub region has made strides towards promoting career guidance and counselling with an aim of producing students who are prepared to make adequate career decisions by the time they complete secondary school and tertiary levels of education respectively. Thus, career decision making is perceived to be a key output of career guidance and counseling among students at all levels of education withZ support from teachers, counsellors, professionals, private sector, old students, and other government officials. The government of Uganda has made effort to invest in career guidance and counseling at all levels of education through infrastructure development, human resource, capacity building, publication and distribution of career guidance materials, and monitoring and evaluation of career guidance and counselling activities in the country. However, there are glaring gaps in human resource, capacity building, inadequate training manuals, lack of career information and standardized assessment tools, high student and career masters/ counsellor ratio, and the general lack of school counsellor education, supervision, and certification at national level. This leaves the quality of career guidance and counselling wanting, a situation which is exacerbated by overconcentration on curricular activities, role conflict on the part of career masters, poor funding, and general attitude towards career guidance and counselling. Effort can be made to improve guidance and in secondary schools by developing locally made standard and user-friendly career guidance materials, increase sensitisation about the importance of career guidance and counselling in schools and the general population, and increase the capacity of teachers in general and counsellors through refresher courses. It's also incumbent for the government to make more effort towards setting guidelines to standardise and regularise training of career counsellors and teachers in teacher training institutions in skills of career guidance and counselling which would be used after training in schools. The schools are encouraged to continue to partner with professionals in the private sector to supplement the existing human resource to fill the man power gaps in career guidance and counselling.
\end{abstract}

Keywords: Career guidance and counselling, guidance and counselling, career decision making, career development, secondary schools, students, job market

\section{Background}

The Republic of Uganda is a landlocked country within East Africa covering 241,550.7 square kilometres with an estimated population of 34.6 million people (Uganda Bureau of Statistics, 2014). Career guidance and counselling in Uganda dates far back in the 1940s when formal education was expanding in the country spearheaded by the missionaries. Educational reforms were made during the pre-independence and post-independence aimed at streamlining career guidance and counselling in schools on the advice of two commissions namely Castle Review Commission of 1962, and Kajubi Review Commission of 1992. In 2008, a fully-fledged department of guidance and counselling with substantial staff was established to provide strategic and technical leadership in all matters of guidance and counselling in schools in Uganda. Its mandate was to design and disseminate programs in schools aimed at meet students career guidance and developmental needs in aspects of HIV/ AIDS counselling, and psychosocial concerns of students(MOES, 2007).

The Ministry of Education and Sports (MOES) oversees the formal education sector in the country which is divided into three main stream sub-sectors namely pre- primary \& primary, post-primary (secondary; business, technical, vocational, education, and farm schools BTVET); and tertiary education (colleges and universities). Secondary school education sub-sector is further divided into two levels; lower secondary (Ordinary Level "O'level") which is covered in four academic years. Students are assisted to select ten subjects on the curriculum which they must sit at the end of the fourth year in national examinations to prepare them to either join a vocational college (BTVET), or continue with upper 
secondary education. The average age of students at O'level is usually sixteen years. Upper secondary in Uganda is also referred to as Advanced Level ( $\mathrm{A}^{\prime}$ level). It is covered in two academic years. A student is assisted to select a subject combination consisting three principle subjects and two subsidiary subject's scholars required by the national curriculum. The process of selecting subject combinations both at lower and upper secondary is performed under career guidance department of respective schools in collaboration with subject teachers, parents, and school administration. The secondary school sub-sector is further classified by government and private partnerships as either Universal Secondary Education (USE) found in both government aided and private secondary schools or Non-Universal Secondary Education (Non- USE) offered both in government aided schools and private schools (Republic of Uganda, 2017).

The introduction of Universal Primary Education (UPE) and Universal Secondary Education (USE) increased student enrolment in schools which further necessitated the promotion of guidance and counselling in schools to meet students' career, emotional, social and physical needs. This development created a paradigm shift from regular career guidance and took on a broader approach to guidance and counselling. This shift was aimed at responding to challenges of increased student enrolment related to future unemployment of school leavers at all levels of education. Increased enrolment further threatened the quality of education through anti- social student behaviours which students engaged such as rampart strikes, teen- pregnancy and early marriage, poor classroom performance, and truancy. This created high levels of school dropout, as well as discrimination and stigma for people with disability, older students, and children infected and affected by HIV/ AIDS scourge. This was further associated with teenage behaviours like drugs and alcohol abuse, and the influence of the wild effects of technology, and lifestyle from the Western world which left many students disoriented and lost track in their educational pursuits (Kiweewa, Knettel, \& Luke, 2017; MOES, 2012; Senyonyi, Ochieng, \& Sells, 2012).

\section{Methodology}

A documentary review was used to establish the activities carried out by the department of career guidance and counselling in the Ministry of Education and Sports (MOES) with regard to general career guidance and counselling programs in secondary schools in Uganda. More information was obtained by analysing related literature both in print and media to analyse the current situation of career guidance and counselling in Uganda. The information obtained was prepared thematically to come out with developments in career guidance and counselling, challenges, and the possible strategies which can be adopted to strengthen career guidance and counselling in Uganda. This information further provides highlights in the current developments in the education sector, and the challenges which are detrimental to the quality of career guidance and counselling in the secondary school sub-sector in Uganda. Suggestions about improvement of career guidance and counselling in the subsector was addressed with an aim of improving career guidance and counselling in schools which would consequently strengthen the quality of students' career decision making both in school and out of school.

\section{Discussion of Results}

The MOES has 4704registered secondary schools and post primary vocational institutes which include Business, Technical, Vocational, and Educational Training Institutions (BTVET). Since the inception of the department of guidance and counselling in 2008 has had some influence on the sector. The total number of post- primary schools visited where career guidance and counselling were provided were 960 . The break down included 786 which were government aided secondary schools, 38technical institutes, 22primary teachers' colleges, and 114 were private secondary schools. The main criterion used while selecting these schools was on the basis of inclusion and exclusion whereby;

- Priority was given to government institutions/ schools

- Schools/ institutions implementing USE programs for secondary schools

- Schools with high student enrolment within the given year

- The location of the school within the traditional regional areas of the country namely Central, Eastern, Northern, and Western

- Centers of excellence for government Non- USE schools

- Resource allocations/ funds released within a quarter of the government financial year.

The main areas of emphasis during the visits in secondary schools and post primary colleges focused on training school teams, and career guidance and counselling. The main aspects of career guidance and counselling for students handled were; education pathways, job placement, career interest, ability, training and job shadowing. Other areas were career development, gender and career decision making, HIV/ AIDS and career growth, inspirational talks, mentoring and coaching especially in teacher training colleges, psychosocial issues in career interest, life skills, and $21^{\text {st }}$ century skills. These trainings were conducted on school basis whereby all students were brought together on a careers day and addressed by the facilitators who were mainly the officials from the department of career guidance and counselling from the MOES. The medium of training for career teachers was on workshops basis lasting between $3-5$ days depending on the availability of funds to cover the length of training. The workshops were conducted and facilitated by guidance and counselling staff from MOES, and other facilitators who were identified to join the team of trainers. The main training manuals used included the Career Guidance Compendium, and National Guidance and Counselling training manuals provided by the department of guidance and counselling of the MOES.

Among the registered achievements during the school visit program, the department was able to design, published and distribute materials for career guidance and counselling to schools which included the Career Guidance handbook, Periodic Career guidance Journal, National guidelines for Post primary institutions, career guidance compendium, and National guidance and counselling training manual. It is hoped that with time, more materials produced to meet guidance 
and counselling needs of students, parents, careers teachers and counsellors in secondary schools and colleges, and also prepare students to respond to global challenges associated with the world of work.

\subsection{Current Developments}

In the report contained in the MOES financial year 2015/ 16 it was revealed that the department of guidance and counselling has also registered further improvement in the general quality of education in the country through capacity building of human resource, increased structural facilities, information resources, and monitoring and evaluation. Capacity building of careers masters at school level has been at the centre of planning for career guidance and counselling development in secondary schools in Uganda. The number of career guidance teachers who have been trained since 2008 to 2014 was 714 teachers altogether from the four traditional regions of Uganda; Central, Western, Eastern, and Northern. The last recorded training of career masters in schools/ post primary institutions took place in 2014. This achievement cannot be underrated however it's a drop in the ocean because the sub-sector has a total of 61,505 teaching staff of which, 26,794 are in government aided schools and 34,711 in private school (Unpublished). This state of affairs leaves a huge manpower gap of trained career guidance masters and counsellors in the education sector required to meet the needs of students thereby affecting the quality of career guidance and counselling in the sub-sector.

Furthermore, secondary schools and colleges have been facilitated to build physical structures to house guidance and counselling order to develop and strengthen counselling among students. It's approximated that $62 \%$ of schools have career guidance and counselling established offices with a designated career master to attend to students' career needs and coordinate career guidance and counselling activities. The main funding bodies of career guidance and counselling programs in schools and colleges have been School Management Committees (SMC), Board of Governors (BOG), and Parents Teachers Associations (PTA). The MOES has been keen on providing technical support through training, information dissemination, distribution of training manuals, coordinating of programs, and monitoring and evaluation. According (Republic of Uganda, 2017) it was reported that as a result of guidance and counselling in schools, there is increased student enrolment, improved awareness and life skills among learners, increased decision making and choice making among students on subjects and career choice, and improved emotional health among learners. it was further reported that the department of Guidance and Counselling registered success in respect to improved school environments for the learners, better informed pupils and students in their career choices in schools and colleges, improved capacity of teachers and guidance counsellors to provide guidance and counselling services, improved awareness of stakeholders for the need and importance of Guidance and Counselling, improved retention and reduced school drop outs, reduction of school based violence and increased enrolment as a result of effective placement service.

Counselling programs at school level have registered developments covering critical aspects of a child's developmental tasks namely; personal guidance, social and psychological guidance, educational guidance, career/ vocational guidance, and spiritual guidance. Schools have various localised school activities in which the outlined aspects of career guidance and counselling are addressed such as careers day, and careers week, new students' orientation, school rules and regulations, weekly class meetings, messages on personal values (talking compounds), Presidential Initiative on AIDS Strategy for Communication to the Youth (PIASCY), peer counselling, student talks over school assembly, and parents during PTA meetings. In addition, career masters and counsellors sometimes arrange for class and dormitory meetings to listen and respond to students concerns either on weekly or monthly basis, while other schools have gone ahead to create families based on small groups of students for mentorship from each other and group mothers/ teachers. Individual is usually ongoing, while referrals are made for those students who require advanced medical and psychosocial support outside school. The human resource utilised to facilitate guidance and counselling activities in school have been school administrators, chaplains, matrons, senior man and senior women, class teachers and sometimes student leaders. Others include old students, professionals, entrepreneurs, religious and political leaders, motivational speakers and sometimes personnel from admissions offices of both private and public tertiary institutions and universities have also been handy in the area of sensitising students on pre- entry requirements for specific courses.

\subsection{Challenges}

Despite the gains made and the education sector generally faces a lot of challenges which have greatly crippled the development of career guidance and counselling the country. Poor supervision of guidance and counselling services has been singled out as a major challenge due to inadequate technical staff and expertise both at national and local government level. This has been coupled with inadequate funds to organise campaigns for creating awareness on importance and role of guidance and counselling in schools. In a study conducted by the one of the national daily newspapers about parents' concerns on secondary education in the country, lack of career guidance was ranked second at $12.5 \%$ after high school dues at $26.5 \%$. it was observed that schools were more concerned about academic scores more than developing students into whole persons (New Vision, 2018).

Further research findings about the state of guidance and counselling in Uganda has revealed that the education sector lack trained school counsellors, while the career masters appointed in schools have dual roles which are not limited to being classroom teachers but have a host of other added responsibilities in school, family, and community. This means that the time spent with students, preparation of career guidance and counselling materials, coordination of career guidance activities, and follow up is limited. Furthermore career masters/ counsellors, lack the ability to interpret and integrate available career guidance and counselling manuals for students which subsequently affects the efficacy of career guidance and counselling programs in schools(Senyonyi et al., 2012). This was further exacerbated by lack of experts and resource persons to facilitate career guidance and counselling in training institutions and at school level. Career guidance and counselling is usually offered as a course unit both in counsellor education and in teacher training 
without any practical lessons, supervision, and certification to ground future school counsellors and teacher trainees in skills of career guidance and counselling. whereas in schools' teachers perceive career guidance and counselling as the duty of career masters it's high time career guidance and counselling is given due respect it deserves as an activity which should be integrated in a teacher's daily activities both in or out of classroom. there's a glaring need to step up school counsellor education and supervision in universities and colleges which offer courses in guidance and counselling both at undergraduate and master's level to train more graduates with necessary skills required to meet career guidance and counselling needs within schools in the country.

It's been further noted that the biggest challenge faced in the area of career guidance and counselling in SubSaharan region and Uganda in particular is lack of structured frame work and guidelines with which career teachers, counsellors, students and parents can work with to facilitate students' career decision making. Most of the information supplied and materials distributed contain general information about guidance and counselling with scanty information and guidelines specific to career guidance and counselling (Wambu, G, W., \&Fischer, 2015). (Mapfumo J., 2013) observed that in spite of clear policy guidelines on how guidance and counselling services should be offered in schools, effectiveness is extremely low which is attributed to lack of support by school heads, limited skills, and user manuals among career teachers and counsellors. Therefore, career guidance and counselling become a haphazard activity which has no standardised guidelines for career masters and counsellors to prepare and deliver effective career guidance and counselling tasks. This also has a ripple effect on training, school career activities inspection, and general professional development and supervision. The product of this career guidance and counselling is likely to be students who may fail to make basic career decision while at secondary school, higher educational institutions, and later on in transition into the job market. (MOES, 2011), it was observed that the most challenge faced by students of senior four (S4) and senior five (S5) is choice of appropriate school and subject combination which was attributed to inappropriate career choice and career preparation. This was reinforced by other factors particularly the ratio of careers teacher/ counsellor to students' which stands at 1:500 in East Africa (Ayiro P.L., 2016) and at 1:1000 in Nigerian schools (Kiweewa et al., 2017).

Career guidance and counselling is still looked at as a strategy to mitigate the threat of HIV/ AIDS from infecting and affecting students, teachers and support staff. For instance, guidance and counselling was ranked as the most utilised method of disseminating HIV/ AIDS information in all secondary schools in Uganda by 20\% (MOES, 2013). Career guidance and counselling is also considered as a tool to guarantee student retention, safety, discipline, and an intervention towards equal opportunities to students in schools. The government documentation on career guidance has little information on career guidance and counselling as a tool of enhancing student's career decision making, career choice and placement framework, and preparing students for their occupational life. Limited research has been conducted about the effectiveness of the existing career guidance and counselling programmes in schools on students' career decision making. This is in respect to students at A'level. A 'level. This is a special interest group of students because they are in their last stage in secondary school education in which students are required to express their academic competence, ability to select proffered subject combinations, and plan for their future careers. Career guidance programs in particular are more emphasised at this stage of education unlike at other stages because students are considered to be at a behavioural and cognitive level where they can make life decisions with support from teachers, professional career counsellors, peers, parents, and other significant professionals in society(Hirschi, 2007; Vernon, 2006).

In Uganda, more factors were examined which influence students' career choices and consequently pose a great challenge to the students in the quality of their career decision making.(Sharf,. R, 2013) observed that adolescents undergo a stage of formal thinking described by Piaget between ages 15 and 16. This developmental stage is a continuation of adolescence where a child multi tasks between physical, psychological, and social development. The adolescents are no longer interested in following rules and being productive but are engaged in questioning the world. Together with the demands from their physical development and exposure to difficult sexual decisions, they are also required to undertake career decisions' which greatly affect the perceptions they hold about the world of work. Therefore, the support they will receive from parents, teachers, counsellors, peers, and other mentors cannot be down played. Besides this, the students are faced with a host of other personal challenges which they must tackle to make sense of their career decisions while at school such as academic competence, interpersonal relationships, respect for social norms, and the adjustment towards the current dynamics associated with the technological world. This puts a lot of pressure on the students; however, those who get solid career guidance and counselling are likely to make competitive career decision while those who are not well supported may encounter problems in the choices they will make in life. In Uganda, there's a general observation that most of the school time is spent on examinable subjects more than career guidance and counselling. In Uganda, schools at all levels including kindergarten start early morning lessons by 6.am and go on up to 10. Pm. Students hardly find time for self management. All the school activities are ordered toward covering the syllabi, assessments, remedial, and the remaining time id divided between co-curricular activities. The child and the teachers alike are stuck in this web which often result into chronic stress and burn out. This situation coupled with lack of orderly career guidance and counselling leaves career development to chance, a reason why most students' career choices are influenced by peers, parent, teachers, and social media. (Wambu, G, W., \& Fischer, 2015) in their study in Kenya revealed that role ambiguity, and lack of career counselling materials were major challenges to career guidance and counselling in schools in the region.

Peer and parental influence have been singled out as a great challenge to students' career decision making. Most parents push their children to choose careers which are not in line with their value system, interest, ability and talents. Some of the preferred choices are guided by traditional beliefs about popular courses which have been overtaken by technological and job market modifications. What should be noted is that most subject combinations offered in schools have been subsequently adjusted to meet needs of the courses offered in institutions of higher learning as well as the job market. This has left many students disoriented whereby they end up taking on subject combinations and courses which 
do not tally with the educational and job market demands. These scenarios consequently affect students' quality of performance in their class work, the skills acquired, and future performance on their jobs. It has been observed that students who have received comprehensive career guidance and counselling programs while in school, they have reported to feel safe while attending their schools, being more satisfied with the quality of education, and believing that education was more relevant to their future careers In a study by (Mghweno, P. E., Mghweno, L. R., \& Baguma, 2014; National Occupational Information Coordinating Committee (NOICC), n.d.). It was further revealed that most students select careers based on personal decision by $87.6 \%$, counsellors and career masters by $3.1 \%$, while $7.8 \%$ is attributed to parents. However they cautioned that much as the majority of students reported to have made personal decisions on career choice, there's a lot of influence by peers. (Ayiro P.L., 2016) , further attested to this finding in their respective studies which showed that by University or college most students lack ideas on courses to study after leaving school a finding which affirms that students involvement and preparation for career decisions is very low than what is perceived(Gallant D.J., 2011; Mapfumo J., 2013) also observed that 50\% of college and university students reported that they had not received any career guidance and counselling while at high school; except that pertaining to personal, social, and HIV/ AIDS related counselling. Therefore, investment in career guidance and counselling is very critical during high school years of students so as to prepare them for university/ college and career preparation demands.

On the part of career counsellors and career teachers, school career guidance and counselling can sometimes be frustrating. The job requires time and exceptional communication skills for one to be able to connect with even the most difficult students and their parents. If a counsellor does it right, they can serve as a secondary parents whom students can trust and confide in; however the separation of roles must be considered if students were to benefit from career guidance and counselling services. (Kiweewa et al., 2017) reiterates that the relationship between teachers and students raises a lot of concern. There are noted contradictions in teaching priorities, knowledge of teaching content and career information, understanding of developmental demands on students and growth of appropriate skills which drives schools into adopting authoritarian teaching style. This consequently promotes discipline among students and teachers, prevents development of healthy interpersonal connection between teachers and students which deprives them of total school needs in terms of physical, emotional, cognitive, and social development.(Gibson L.Robert, 1990; Gysbers, 2015) highlighted key aspects essential to career guidance and counselling in school settings, among them is the ability to consider the student's unbiased base from which he/ she can develop a positive attitude and respect for honest work, stimulation of the students' educational programs, teaching students to view career as a way of life, and education as preparation for life. This follows an assumption that career counsellors and teachers are perceived to be involved in assisting students to understand themselves, providing understanding of the relationship between education and career; the perspective of time frame between school and work, and the opportunities for career experiences. However practically it's far from real because of role conflict among career teachers, school counsellors and other school demands. Most of them carry double roles with high teaching load, coupled with they lack skills, and attitude held about career guidance. In most schools, career masters and school counsellors are locally appointmented without a clear recruitment policy. Most of them are appointed according to the discretion of head teachers either on the basis of experience in school such as senior teachers, the office held like director of studies or deputy head teacher in charge of academics and discipline, class teachers, or school religious leaders. This is done with disregard for background check on individual professional training, availability of career materials for use, time allocation on the time table, and acknowledge of duties and responsibilities. The staff recruited sometimes are handicapped in their performance due to lack understanding of scope of professional practice and ethical issues related to their duo roles (Kiweewa et al., 2017; Senyonyi et al., 2012; Wambu, G, W., \& Fischer, 2015)

\subsection{Suggestions Aimed at Improving Career Guidance and Counselling in Schools}

Career guidance and counselling in schools could be strengthened by promoting the development and domestication of career guidance and counselling tools and techniques; develop user friendly career assessment tests, and lobby for increased financial and logistical support from the government. Again more energy needs to be directed towards legalisation and professionalization of guidance and counselling in the country through legal mandate of operation counselling in the country, creation of uniform standards for training and accreditation of courses, professional development through associations of counsellors, and licensure requirements for practice for school and nonschool counsellors (Senyonyi et al., 2012; Kiweewa et al., 2017). This will greatly improve career decision making which is part and parcel of a child's cognitive and behavioural development. It involves activities like collecting, appraising, organising, and analysing information leading to a conclusion in which a person makes emotional and behavioural commitment. (Gibson L.Robert, 2007; McLoed J., 2011) observed that career development cannot be separated from an individual's social, physical, emotional and educational development. They identified three common experiences which human beings experience in career development namely development and growth, education, and work experience. Work experience begins in one's youth through adulthood and it is shaped through school setting by learning, living with others, and working.

The role of career guidance and counselling programs in school should again be tailored to focus on facilitating and enhancing the school's contribution towards learning, growth, and development in preparation for work by the youth. Thus career guidance and counselling programs in schools should be aimed at promoting a person's career development, planning, and decision making within the educational context (Baskin \& Slaten, 2014; Gibson L.Robert, 2007). Schools could also adopt whole school comprehensive guidance and counselling which has been advocated for to address all the three domains of learning; knowledge, affective, and psycho motor. This draws on ability of career masters, career counsellors, and schools in general to integrate career guidance and counselling in school curricular and teacher training to address the challenges associated with limited human resource to offer career guidance in schools. This effort will also 
enable teachers to take on multiple roles to support the career development and wellbeing of children in school (Kiweewa et al., 2017).Worldwide there's a big challenge of integrating career guidance and counselling programs into the curriculum. Career guidance and counselling is often pushed aside without appreciating the fact that academic achievement is affected by the students' personal and social development. Uganda is equally affected evidenced by the fact that most of the time on the school time table is occupied by subjects on the curriculum with very little space left for cocurricular. Career guidance is conducted on specific official days during the term time on which parents, teachers and students meet to guide career decision making process. This is aggravated by the fact that the students are too many to be seen in one day, and sometimes some parents do not appear at all which leaves their children to select career choices on their own or may end up taking on their peers' advice.

Schools in Uganda faces a challenge of translating career guidance and counselling service delivery from helping students decide on courses of study and future possible jobs, to nurturing career development skills. it should be noted that if factors such as appropriate career service provision at school level were well structured with an aim of supporting students towards decision making on immediate career choices, personal development, and lifelong career planning, it would create a strong bond between the learner and the curriculum which would consequently produce students who are confident about their career development. Kozlowski, (2012) proposed a paradigm shift from the idea that the curriculum and career counselling should be classroom activities to creating single, integrated lessons that simultaneously address academic, personal, social, and career needs of all students. Alcohol and substance abuse have greatly derailed some students from their initial career paths. It is a common to find that adolescents are pressured into drinking alcohol or trying other drugs in order to get their peers' approval. Therefore career guidance and counselling programs aimed at raising awareness about the effects of addictive and substances of abuse to the students is very critical and how it affects their academic performance and career preparation. (Boitt, 2016) observed that without sound guidance and counselling many student's loose direction and engage themselves in bad behaviours such as drug abuse, and alcohol indulgence, truancy, and juvenile delinquency which is recognised as a major factor responsible for early school drop- out, poor grades, incompetence on future jobs, and generally difficulty in career development. Therefore, career guidance and counselling require collaborative effort from all staff members, administrators, parents, peers, and the community to allocate sufficient time on school timetable and outside school so as to support students' initiative towards their career development.

Other factors have been identified to have influence on students' ability to make career development either directly or indirectly. Career development is not entirely an individual student, career teacher, career counsellor, or school problem, but a combination of other factors. Some students may experience problems outside school originating from relationships within family and home such as abuse, domestic violence, separation and divorce of parents. If not, some parents may lack the quality time they spend with their children which may cause stress and reduced confidence to children during times of career decision making. Some adolescents also have a hard time talking to their parents regarding personal matters like peer pressure and maladjustment issues such as intense sexual pressure, early sex, bullying, discrimination and stigma resulting from either delayed or early onset of developmental changes. This may be coupled with personal identity issues, demands on school rules and regulations and class work difficulties. Students need an unbiased opinion of an adult from time to time to support them in their career prospects so as reach career maturity and are able to make enduring career decisions. (Sharf. R, 2005) citing Scott and Church, observed that family relationships do affect an individual's career development. In their study, Scott and Church discovered that enmeshed and disengaged family relationships were strong predictors of career development than other factors like gender, social- economic status, or education achievement. Their study further revealed that children from non- divorced families had good decisionmaking ability than those from divorced families especially recent ones. Use of family systems theory where affected students could be guided through family genograms is one way of intervention for self-discovery and gathering relevant information about the child. The school counsellor/ career master can utilise this information to help students modify their attitude toward self, education, future world of work. This information can also be used to identify family models that can inspire the student in question to make proper career decisions and career development. This view was shared by the Philips developmental -relations model which stipulates that the actions of others and self-directedness can greatly influence how individuals use career information either positively or negatively towards their career choice (Sharf, 2005).

Lastly, a high school counsellors and career masters could be encouraged to adapt and emphasize the ideas and prospect for secondary school students to explore more information about available career paths, occupations, and provide access to computerised career search engines so as to give them variety information from which they can base their career decisions both in and after high school. Some individuals are unsure of what they want to do with their lives after leaving school. (Race, 2010) noted that with the current changing trends in the economy, no one has a lifetime employment. Learning provides students an opportunity to become ready for one of their main features in life, which is getting a job and staying in employment. Therefore, secondary schools in Uganda must create an environment to equip students with personal qualities, core skills, and process skills. These would subsequently step-up students' opportunities and abilities towards personal career development characterised by educational values inculcated among students namely, wanting to learn, taking ownership of wanting to learn, learning by doing, making sense of what has been learned, learning through feedback, learning through explaining, and learning through assessing informed judgement for one to make career decisions. Adoption and integration of career counselling theories would be helpful in strengthening career guidance and counselling in schools. Holland's theory of six personality types further provides vital information which career masters and counsellors can utilise for career guidance and counselling not only for students but also people facing difficulties in their career transitions. Information about personality type is divided into six sub- types which are matched with occupations and school subject combinations. The main personality areas include realistic, investigative, artistic, 
social, and conventional. Choosing a career or educational program which fits your personality is a vital step toward career well- being, job satisfaction, good grades, and graduation on time (Holland, 2017).

\subsection{Conclusion and Way Forward}

Career guidance and counselling as a process spans through lifetime, therefore in Uganda, career guidance and counselling programs in school's ought to be reinforced early enough to create an environment in which individual students will be supported to make appropriate career decisions which will prepare them adequately for national, regional, and global challenges associated with the world of work. The onus is on schools, students, teachers, parents, government, and other significant stake holders to facilitate curriculum and career development among students in terms of increased advocacy for career guidance and counselling, capacity building, availing counselling materials and resource centres to enable students' access updated career information, and create opportunities for benchmarking. Strong collaboration between government, schools, and the private sector will create opportunities for students and career masters and counsellors to identify gaps in their service delivery and job market requirements from the education sector. Institutions of higher learning hold high stake in students' career development in respect to information and skills development, mentor ship, and training of professionals who will work with students at lower levels of education towards shaping their career paths. In addition, education standards and professional bodies should be encouraged to be more visible in creating an enabling environment, establish structures for certification and supervision of career guidance and counselling in schools, and also provide overseer role in the development of career guidance and counselling materials such as assessment tools, manuals for practice and training which meet international standards.

\section{References}

i. Ayiro P.L. (2016, April). East Africa: Career Choices - Dilemmas Facing Varsity Students.

ii. Baskin, T. W., \& Slaten, C. D. (2014). Counseling Approach : Linking Contextual Psychotherapy With the School Environment. https:// doi.org/ 10.1177/ 0011000012473664

iii. Boitt, M. L. J. (2016). Evaluation of the Challenges in the Implementation of the Guidance and Counselling Programme in Baringo County Secondary Schools , Kenya, 7(30), 27-34.

iv. Gallant D.J., \& Z.J. (2011). High school students' perceptions of school counselling services; awareness, use, and satisfaction. Journals- Sage Publications. https:/ / doi.org/ doi/ abs/ 10.1177/ 2150137811402671

v. Gibson L.Robert, M. H. M. (1990). Introduction to Guidance and counselling. (Robert Miller, Ed.) (3rd ed.). NY: MacMillan. https:// doi.org/ 0131738216

vi. Gibson L.Robert, M. H. M. (2007). Introduction to Guidance and Counselling (7th ed.).

vii. Gysbers, N. C. (2015). Counseling Psychology and School Counseling Partnership:, 32(2), 245-252. https:/ / doi.org/ 10.1177/ 0011000003261355

viii. Hirschi, A. (2007). Readiness to a Six-Phase Model of Career Decision Making, 164-191.

ix. Holland, J. (2017). Holland 's theory of career choice. Retrieved from https:/ / www.careers.govt.nz/ assets/ pages/ docs/ career-theory-model-holland-20170501.pdf

x. Kiweewa, J. M., Knettel, B. A., \& Luke, M. M. (2017). Incorporating Comprehensive Counselling and Guidance Models into School Curricula in Sub-Saharan Africa. Springer, 35(3). https:// doi.org/ 10.1007/ s10447-017-9316-9

xi. Mapfumo J., \& N. E. (2013). Freshmen: Guidance and counselling received in High school and that needed in University. International Journal of Scientific and Research Publications., 3(12). Retrieved from www.ijsrp.org

xii. McLoed J., \& M. J. (2011). Counselling skills. Practical guide for counsellors and helping professionals (2nd Ed) (2 nd). NY: Hill, McGraw.

xiii. Mghweno, P. E., Mghweno, L. R., \& Baguma, P. (2014). (2014). Access to counselling and guidance services and its influence on students'school life and career choices. AfricanJournalofCounsellingandGuidance, 1((1)), 7- 15.

xiv. MOES. National guidelines for post- primary institutions, guidance and counselling programmes (2007).

xv. MOES. (2011). Journal of Guidance and counselling, 1(Jan/ Feb 2011).

xvi. MOES. (2012). Journal of Guidance and counselling. Kaampala: Republic of Uganda.

xvii. MOES. (2013). Education Abstract.

xviii. National Occupational Information Coordinating Committee (NOICC). (n.d.). Academic Innovations, Publisher of Career Choices. Retrieved from http:/ / www.academicinnovations.com/ noicc.html

xix. Race, P. (2010). Making Learning Happen, 2nd Edition: A Guide for Post-Compulsory Education (2nd ed.). London: SAGE Publication.

xx. Republic of Uganda. (2017). EDUCATIONAND SPORTS SECTOR: Annual Performance Report Financial Year 2016 / 17. Kampala: MacMillan.

xxi. Senyonyi, R. M., Ochieng, L. A., \& Sells, J. (2012). The Development of Professional Counseling in Uganda : Current Status and Future Trends, 90(October).

xxii. Sharf. R. (2005). Applying Career Development Theory to Counseling (4th ed.).

xxiii. Sharf. R. (2013). Applying Career Development Theory to Counselling (6th ed.). Belmont: Brooks/ Cole CENGAGE Learning.

xxiv. Uganda Bureau of Statistics. (2014). Uganda Bureau of Statistics Statistical Abstract, 1-305. Retrieved from http:/ / www.ubos.org/ onlinefiles/ uploads/ ubos/ statistical abstracts/ Statistical Abstract 2014.pdf

xxv. Vernon, Z. G. (2006). Career Counselling. A Holistic Approach (7th Ed.).

xxvi. Vision, N. (2018, January 23). Schools guide; parents' concerns on secondary schools in Uganda.

xxvii. Wambu, G, W., \& Fischer, A. . (2015). School guidance and counseling in Kenya. Historical development, current status, and future prospects. Journal of Education \& Practice, 6(11). 